\title{
Anaerobic Treatments for Dairy Waste Disposal - Ponder for making it Efficient
}

\author{
Kanchan V. Mogha ${ }^{1}$, Kunal M. Gawai ${ }^{1}$ and Arun C. Patel ${ }^{2}$ \\ ${ }^{1}$ Department of Dairy Microbiology, Sheth M. C. College of Dairy Science, \\ Anand Agricultural University, Anand - 388 110, Gujarat, India \\ ${ }^{2}$ Department of Dairy Technology, G. N. Patel College of Dairy Science and Food Technology, \\ S.D.A.U., Dantiwada- 385506, Gujarat, India \\ *Corresponding author
}

A B S T R A C T

Dairy sector in India plays an important role in the socio-economic

Keywords

Dairy, India, Socio

economic, Oyster,

Nutritional.

Article Info

Accepted:

10 September 2017

Available Online:

10 November 2017 development and constitutes an important segment of the rural economy. Dairy industry provides livelihood to millions of homes ensuring supply of quality milk and milk products to the people in both urban and rural areas. India is world's largest milk producers accounting for around $17 \%$ of the global milk production and known as 'oyster' of the global dairy industry. Besides it is one of the largest consumers of the dairy products. Due to their nutritional qualities, the consumption of dairy products has been growing exponentially in the country which thereby leads to increase in waste effluent. Anaerobic treatment is the best method employed for treating these wastes.

\section{Introduction}

Milk production in India has risen by a historic $6.25 \%$ in 2014-15, reaching 146 million tonnes as anticipated (Rajeshwaran and Naik, 2016). In the year 2012, the total milk production in the country was over 121.8 million tonnes with a per capita availability of $281 \mathrm{gm} /$ day (GOI, 2012). Milk production in India was around 35\%, of which the organized dairy industry account for $13 \%$ of the milk produced, while the rest of the milk was either consumed at farm level or sold as fresh non-pasteurized milk through unorganized channels. Dairy Cooperatives account for the major share of processed liquid milk marketed in the India. Milk is processed and marketed by 170 Milk Producers' Cooperative Unions, which federate into 15 State Cooperative Milk Marketing Federations. Over the years, several cooperative brands have been arisen like Amul (GCMMF), Vijaya (AP), Verka (Punjab), Saras (Rajasthan), Nandini (Karnataka), Milma (Kerala) and Gokul (Kolhapur). Exports of dairy products have been growing at the rate of $25 \%$ per annum in the terms of quantity and $28 \%$ in terms of 
value since 2001. Significant investment opportunities exist for the manufacturing of value added milk products like milk powder, packaged milk, butter, ghee, cheese and ready to drink milk products.

With growth of industry pollution caused by it due to discharge of dairy effluents is a serious concern not only in India but throughout the world. The food sector has one of the highest water consumptions and is one of the biggest producers of effluent per unit of production besides it also generates a large volume of sludge in biological treatment. Dairy effluents are nutritious as it contain fat, protein and carbohydrates and if not treated properly prone to increase pollution by many folds (Ramjeawon, 2000).

\section{Waste-water treatment - unit operations and processes}

Waste water treatment methods are broadly classifiable into physical, chemical and biological processes:

Physical unit operations include screening, comminution, flow equalization, sedimentation, floatation, granular medium filtration etc.

Chemical unit operations include chemical precipitation, adsorption, disinfection, dechlorination etc.

Biological unit operations include activated sludge process, aerated lagoon, trickling filters, rotating biological contactors, pond stabilization, anaerobic digestion and biological nutrient removal etc.

\section{Options for waste treatments of water of milk based food industry}

Dairy industries may opt for such treatments which are suitable for reuse or recycling or discharge dairy waste in to local sewers under a trade waste agreement (with prior pretreatment as made necessary) or after appropriate treatment may opt for land discharge wherever practicable, legal and environmentally beneficial.

Best practice for waste water treatment is shown in Figure 1.

Physical and chemical treatments are primary operations and they need strong further treatment depending on the organic load of the effluents. There are basically two types of biological waste water treatment systems; aerobic and anaerobic systems. In view of high biochemical oxygen demand (BOD) load, aerobic processes suitable for low organic load and anaerobic processes for high organic loads are generally adopted for the treatment of waste water generated from milk based food industry. The selection of processes for any particular plant will depend upon the size of the problem, location of the plant and the necessary degree of treatment required (Sharma, 2008).

\section{Aerobic treatment}

Aerobic biological treatment involves microbial degradation and oxidation of waste in the presence of oxygen. Conventional treatment of dairy waste water by aerobic processes include processes such as activated sludge, trickling filters, aerated lagoons and or a combination of these (Carta-Escobar et al., 2004). All compounds of dairy waste water are bio-degradable except protein and fats which are not easily degraded (Omil et al., 2003).

\section{Anaerobic treatment}

Owing to the presence of high organic matter, dairy waste waters are well suited for biological treatment, especially anaerobic 
treatment (Rico et al., 1991). However, the presence of fat shows the inhibitory action during anaerobic treatment of dairy waste waters (Vidal et al., 2000). This inhibition is due to the presence of long chain fatty acids formed during the hydrolysis of lipids, which causes retardation in methane production (Hanaki et al., 1981). Long chain fatty acids were reported to be inhibitory to methanogenic bacteria (Koster, 1987) but lipids do not cause serious problems in aerobic processes (Komatsu et al., 1991).

Anaerobic treatment is a biological process ideally suited for the pre-treatment of high strength wastewaters that are typical of many industrial facilities of present era. Anaerobic digestion is a process in which microbes stabilizes organic matters in the absence of oxygen with the production of biogas (methane and carbon dioxide) along with increment in biomass and inorganic products. The process reactors are designed in such a way that it would prevent the introduction of air and the release of odour from the chamber (Lusk, 1998).

It includes four reaction stages to convert insoluble particulate organic material in to two final chemical products i.e. $70 \% \mathrm{CH}_{4}$ and $30 \% \mathrm{CO}_{2}$. These stages are: hydrolysis (by hydrolytic bacteria), acidogenesis (by acidogenic bacteria), acetogenesis (by acetogenic hydrogenating and dehydrogenating bacteria) and methanogenesis (by hydrogenotrophic and acetoclastic bacteria) (Tie and Shivkumar, 2006).

Anaerobic process possesses inherently several prominent advantages over an aerobic process, such as lower energy requirement, recovery of methane as energy source and lower sludge production and thereby leads to low nutrient requirements. The process can operate at low hydraulic retention time (HRT) achieving a very high chemical oxygen demand (COD) of process loads and can withstand to a wide fluctuation in influent feed characteristics and free from requirement of mixing. Effluent in anaerobic digester with very high loading rate of $31 \mathrm{~kg} \mathrm{COD} / \mathrm{m}^{3} \mathrm{~d}$ has been reported in literature (Rico et al., 1991). The anaerobic ecosystem is the result of complex interactions among microorganisms of several different species. In view of the current problems, both in the protection of the environment and in the search for sources of renewable energy, anaerobic digestion appears to be a favourable biotechnological process to treat an organic waste through bioconversion into energy. Smaller reactor size is required in anaerobic digester contrary in aerobic system viz. aerated lagoons, oxidation ditches, stabilization ponds, trickling filters and biological discs requires larger land area.

Consequently, a number of studies have been reported for the treatment of dairy waste water by anaerobic methods. Up-flow anaerobic Sludge Blanket (UASB) reactors have been widely used for the dairy waste water treatment in full scale applications (Rico et al., 1991; Hwang and Hansen, 1992; Gavala et al., 1999). The basic elements of a typical UASB reactor are a sludge blanket, influent distribution system, gas solid separator and the effluent withdrawal system. In the UASB reactor, the influent is distributed at the bottom and travels in up flow mode (Tchobanoglous et al., 2003). Table 1 summarizes the conditions of some anaerobic treatments of dairy waste waters reported by various authors. In one of the studies, COD reduction of $90 \%$ at organic loading rate of $0.031 \mathrm{~kg} \mathrm{COD} / \mathrm{m}^{3} \mathrm{~d}(\mathrm{t}=0.07 \mathrm{~d})$ was achieved operating in steady state conditions using a waste water with influent of $2050 \mathrm{mg} / \mathrm{l}$ of COD. Dairy waste water contains fats and the inhibitory action of the fat to the anaerobic treatment does not allow 
fast and increased removal efficiency (Vidal et al., 2000). Some authors reported that the enzymatic hydrolysis of fats as pre-treatment may remove this problem. Cammarota et al., (2001) found that treatment of dairy waste waters containing elevated fat and grease levels $(868 \mathrm{mg} / \mathrm{l})$ in a UASB reactor resulted in effluents of high turbidity (757 NTU), volatile suspended solids (VSS) up to 944 $\mathrm{mg} / \mathrm{l}$ and COD removal below $50 \%$. However, the same dairy waste water pretreated with $0.1 \%$ (w/v) of fermented babassu cake containing Penicillium restrictum lipases showed higher COD removal efficiency of $90 \%$ when treated in the same UASB reactor.

In another study, Leal et al., (2006) used synthetic dairy waste water containing high levels of oil and grease (200, 600, and 1000 $\mathrm{mg} / \mathrm{l})$ using two identical UASB reactors, one fed with waste water from enzymatic hydrolysis step and the other with raw waste water. 90 and $82 \%$ COD removal efficiencies were achieved in the reactors fed with the hydrolyzed effluent and with raw waste water, respectively. Some authors have reported contradictory reports stating reduced efficiency of continuous UASB reactors due to the buildup of organic matter (MottaMarques et al., 1990; Morgan et al., 1991). Nadais et al., (2005) studied the intermittent operation of mesophilic UASB reactors to overcome the buildup of organic matter and the influence of cycle duration in the reactor.

They reported that a $96 \mathrm{~h}$ cycle $(48 \mathrm{~h}$ feed + $48 \mathrm{~h}$ feed less) reflected the highest conversion to methane. Anaerobic filter reactors are generally suitable for dairy effluents containing low concentrations of suspended solids (SS). The anaerobic filter reactors capture SS and provide sufficient retention time for bio-solids. Hence, the SS retention time and the hydraulic retention time necessarily become satisfying. A laboratory scale plastic medium anaerobic filter reactor provided average COD removal rates between 78 and $92 \%$ at a HRT of $4 \mathrm{~d}$ (Viraraghavan and Kikkeri, 1990; 1991).

Monroy et al., (1994) investigated the performance of an up-flow anaerobic filter reactor treating a high solid containing dairy waste at $0-18 \mathrm{~kg} \mathrm{COD} / \mathrm{m}^{3} \mathrm{~d}$ organic loading. The mean COD removal was found to be $70 \%$. The type of support media (porous or non-porous) greatly affects the reactor's performance in anaerobic filter reactors. The ideal packing media for the anaerobic filter is that which maximizes both the surface area and the porosity. A large surface area of the media enhances the attachment of the biomass and increased porosity decreases the overall reactor volume required and also minimizes the filter clogging. The performances of porous and non-porous support media in anaerobic filter reactors on mesophilic anaerobic treatment of milk bottling plant waste water were investigated and it was concluded that the reactor with non-porous packing showed instability above an organic loading of $4 \mathrm{~kg} \mathrm{COD} / \mathrm{m}^{3} \mathrm{~d}$, whereas the reactor with the porous packing was stable at very high organic loading of $21 \mathrm{~kg} \mathrm{COD} / \mathrm{m}^{3} \mathrm{~d}$ (Anderson et al., 1994).

The strength and the performance of a porous media in an up-flow anaerobic filter (UFAF) were investigated by Ince et al., (2000) up to an organic loading rate of $21 \mathrm{~kg} \mathrm{COD} / \mathrm{m}^{3} \mathrm{~d}$ with a HRT of $0.5 \mathrm{~d}$. The highest quantity of the attached biomass (103 mg VSS/media ring) was found at the bottom and the lowest (23 $\mathrm{mg} \mathrm{VSS} /$ media ring) at the top. After 8 months of operation, a reduction in compressive strength was $50 \%$ of the media, and during this time $80 \%$ COD removal efficiency was achieved. Due to the gas generation, all types of anaerobic reactors are well mixed but the reactor performance gets affected by the degree of mixing and the solid content in the waste. 
Fig.1 Practice for waste water systems (adapted from EPA 1997)

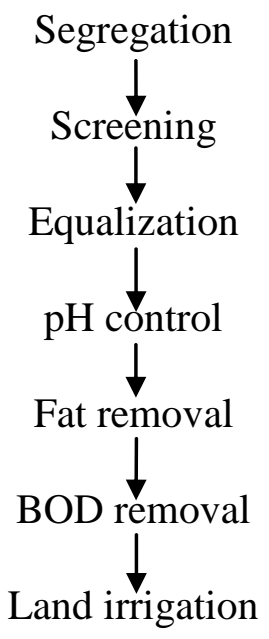

Table.1 Reported conditions for the anaerobic treatment of dairy industry waste waters

\begin{tabular}{|c|l|c|c|c|l|}
\hline $\begin{array}{c}\text { Waste } \\
\text { Type }\end{array}$ & Reactor Type & $\begin{array}{c}\text { \% COD } \\
\text { reduction }\end{array}$ & $\begin{array}{c}\text { COD Loading } \\
(\text { Kg COD } / \mathbf{m 3 ~ d})\end{array}$ & $\begin{array}{c}\text { HRT } \\
(\mathbf{d})\end{array}$ & \multicolumn{1}{|c|}{ Reference } \\
\hline SD & $\begin{array}{l}\text { UASB Control } \\
\text { Reactor }\end{array}$ & $82-88$ & & & Leal et al., 2006 \\
\hline DID & UASB and AS* & 98.9 & & 1.08 & Tawfik et al., 2008 \\
\hline DI & $\begin{array}{l}\text { Two UASB in } \\
\text { parallel }\end{array}$ & 90 & 5.5 & 0.70 & Passeggi et al., 2009 \\
\hline CP & UASB & 90 & & & Cammarota et al., 2001 \\
\hline RM & AF & 90 & $5-6$ & & Omil et al., 2003 \\
\hline SD & BFBR & 96.25 & 10 & & Haridas et al.,2005 \\
\hline MB & UFAF & 80 & 21 & $0.50 \mathrm{~d}$ & Ince et al., 2000 \\
\hline SD & Hybrid & $90-97$ & $0.82-6.11$ & $4.1-1.7 \mathrm{~d}$ & Ramasamy et al., 2004 \\
\hline IC & ASBR & 62 & & $0.25 \mathrm{~d}$ & Calli and Yukselen, 2002 \\
\hline DI & ASBR & $>80$ & $\left(1.6 \times 10^{-3}\right)-$ & $(40-5) \mathrm{d}$ & Goblos et al., 2008 \\
\hline DI & $\begin{array}{l}\text { Anaerobic } \\
\text { Reservoir }\end{array}$ & $>75$ & & & Arbeli et al.,2006 \\
\hline
\end{tabular}

SD-Synthetic dairy, RM-Raw Milk, DID-Dairy Industry and Domestic, CP-Cheese production, IC Ice-cream, MBMilk bottling, DI-Dairy Industry, ASBR-Anaerobic sequencing batch reactor, UFAF-Up flow anaerobic filter, UASB-Up flow anaerobic sludge blanket, AS-Activated sludge, AF-Anaerobic filter. \# 75\% BOD reduction, @ $>75 \%$ BOD reduction, $99.6 \%$ BOD and $98.9 \%$ oil and grease reduction.

The fluidized bed reactors removed the problem of mixing and give better mass transfer characteristics; however, they require a long time for stable bio-film establishment. The "two-stage" reactor concept improves process stability and efficiency and in particular suitable for dairy waste waters containing high concentrations of organic suspended solids (Demirel et al., 2005). In a two-stage system, acidogenic and methanogenic phases can be operated separately under respective optimum conditions. In the first stage, hydrolysis and degradation of lipids and proteins into amino acids and fatty acids take place (Malaspina et al., 1995). This degradation gives a high 
energy yield to the microorganisms. In the second stage the end products of the fermentation process (acetate, butyrate, propionate, formic acid, carbon dioxide, and hydrogen) are produced by methanogenic microorganisms into methane and carbon dioxide.

Yu and Fang (2002a) studied acidogenesis of a dairy waste water in batch reactors at $\mathrm{pH} 5.5$ at $55{ }^{\circ} \mathrm{C}$ with reactors feed of $8000 \mathrm{mg} / \mathrm{l}$ of COD. At the start, the concentration of acetate and butyrate increased rapidly and reached maxima at some points and then declined. Increased in butanol and propanol fractions were reported with increase in substrate concentrations. After higher loading of more than $8000 \mathrm{mg} / \mathrm{l}$ of COD, the metabolism shifted to the alcohol producing pathways. Temperature and $\mathrm{pH}$ are important parameters in treatment with two stage anaerobic reactors. Degradation efficiency is generally more at higher temperatures (Ghosh, 1991). Thus, the thermophilic operation facilitates the treatment at higher loading rates and therefore requires smaller treatment plants than the mesophilic systems. Yu and Fang (2002b) reported that degradation of dairy waste water pollutants increased with an increase in $\mathrm{pH}$ from $\mathrm{pH} 4.0$ to 5.5 and observed $48.4 \%$ COD was converted into volatile fatty acids and alcohols, $6.1 \%$ into hydrogen and methane, and the remaining $4.9 \%$ into biomass. On increasing the $\mathrm{pH}$ up to 6.5 , there was very slight increase in degradation. HRT is also an important variable in two stage anaerobic treatment processes. The effects of HRT on anaerobic acidogenesis have been investigated earlier by Horiuchi et al., (2002). The performance of a mesophilic acidogenic reactor was evaluated in terms of volatile fatty acid production with respect to HRT variations between 1-0.5 d with the organic loading rate of about $9.3 \mathrm{~kg}$ $\mathrm{COD} / \mathrm{m}^{3} \mathrm{~d}$, in a continuous flow completely mixed anaerobic reactor, coupled with a conventional gravity settling tank and a continuous recycling system. It was shown that, acid production increased proportionally to the organic loading rate with decrease in HRT. The highest degree of acidification and the rate of acid production were $56 \%$ and 3.1 $\mathrm{kg} / \mathrm{m}^{3} \mathrm{~d}$ respectively at $0.5 \mathrm{~d}$ of HRT. This supported that variations in HRT affected the volatile fatty acids production (Demirel and Yenigun, 2004).

Anaerobic processes treat only the carbonaceous pollutant with subsequent production of methane while nitrogenous organic material is partly converted to ammonia which also not desirable. It also removes phosphorus in low concentrations. For treatment of dairy waste by biological means anaerobic operations require additional treatment like subsequent processing by aerobic means for maximum degradation of biological waste. It has conditioned with discharge of treated water fully compatible with a good quality standard in to the natural environment (Montuelle et al., 1992). For this a hybrid system comprising of both anaerobic and aerobic reactor are recommended to use for treating dairy waste waters.

The combination of a UASB and activated sludge (AS) gave an overall removal efficiency of $98.9 \%$ for COD, $99.6 \%$ for $\mathrm{BOD}_{5}$, and $98.9 \%$ for oil and grease at a total HRT of $1.08 \mathrm{~d}$ and with $1.9-4.4 \mathrm{~kg} \mathrm{COD} / \mathrm{m}^{3} \mathrm{~d}$ of organic loading. Total Suspended Solids (TSS) and Volatile Suspended Solids (VSS) removal averaged above 72 and $75 \%$, respectively (Tawfik et al., 2008). Donkin and Russell, (1997) fed dairy waste water to anaerobic and anoxic reactors with an aerobic reactor in series. The overall system was operated at an HRT of $7 \mathrm{~d}$. Overall COD and total nitrogen removal was more than 90 and $65 \%$ respectively. Successful anaerobic treatment of waste waters discharged by raw milk quality control laboratories was achieved 
in SBR with an anaerobic filter (AF) without fat removal prior to the anaerobic reactor, with the COD removal being higher than $90 \%$ in $\mathrm{AF}$ and most of the fat was degraded successfully (Omil et al., 2003).

\section{Favorable conditions for inclusion of anaerobic treatment in waste disposal}

High energy requirement by aerobic treatment methods is the primary drawback, which may over come with opting for anaerobic processes. Dairy effluents have high COD and organic content and usually remains warm, enabling to be ideal for treating by anaerobic treatment (Wheatley, 1990). Furthermore, no requirement for aeration, low amount of excess sludge production and low area demand are additional advantages of anaerobic treatment processes in comparison to aerobic processes (Vidal et al., 2000). At the same, there is need for $\mathrm{pH}$ maintenance because it may changes during the digestion of lactose and which is not desirable in anaerobic treatment.

\section{Epilogue}

Bio-treatment leading to bioconversion of the waste materials is probably the most cost effective technique for managing and utilizing waste. Among them, anaerobic digestion is an efficient, small carbon footprint and sustainable technology that should be applied in dairy industry which have high through-put of organic load. It has the potential not only to minimize the environmental impacts but also to maximize resource recovery especially generation of useful renewable bio-fuel (methane) including reuse of wastewater. In order to design and operate anaerobic digestion systems efficiently strategy based approach need to be developed based on requirement of industry, average load of influent, product handling profile of plant and influent characteristics etc.

\section{References}

Anderson, G. K., Kasapgil, B. and Ince, O. 1994. Comparison of porous and nonporous media in up-flow anaerobic filters when treating dairy wastewater. Water Research, 28(7): 1619-1624.

Arbeli, Z., Brenner, A. and Abeliovich, A. 2006. Treatment of high strength dairy wastewater in an anaerobic deep reservoir: analysis of the methanogenic fermentation pathway and the ratelimiting step. Water Research, 40:36533659 .

Calli, B. and Yukselen, M. A. 2002. Anaerobic treatment by a hybrid reactor. Environmental Engineering Science, 19:143-50.

Cammarota, M. C., Teixeira, G. A. and Freire, D. M. G. 2001. Enzymatic pre-hydrolysis and anaerobic degradation of wastewaters with high fat contents. Biotechnology letters, 23:1591-1595.

Carta-Escobar, F., Pereda-Marin, J., AlvarezMateos, P., Romero-Guzman, F., DuranBarrantes, M. M. and Barriga-Mateos, F. 2004. Aerobic purification of dairy wastewater in continuous regime. Part I: analysis of the biodegradation process in two reactor configurations. Biochemistry and Engineering Journal, 21:183-191.

Demirel, B. and Yenigun, O. 2004. Anaerobic acidogenesis of dairy wastewater: the effects of variations in hydraulic retention time with no $\mathrm{pH}$ control. Journal of Chemical Technology and Biotechnology, 79:755-760.

Demirel, B., Yenigun, O. and Onay, T. T. 2005. Anaerobic treatment of dairy wastewaters: A review. Process Biochemistry, 40:2583-2595.

Donkin, M. J. and Russell, J. M. 1997. Treatment of a milk powder/butter wastewater using the activated sludge configuration. Water Science Technology, 36(10):79-86.

Environmental Guidelines for the Dairy Processing Industry 1997. Environment 
Protection Authority State Government of Victoria, 14.

Gavala, N., Kopsinis, H., Skiadas, I. V., Stamatelatou, K. and Lyberatos, G. 1999. Treatment of dairy wastewater using an up flow anaerobic sludge blanket reactor. Journal of Agricultural Engineering and Research, 73:59-63.

Ghosh, S. 1991. Pilot scale demonstration of two-phase anaerobic digestion of activated sludge. Water Science Technology, 23(7-9):1179-1188.

Goblos, S. Z., Portoro, P., Bordas, D., Kalman, M. and Kiss, I. 2008. Comparison of the affectivities of two phase and single phase anaerobic sequencing batch reactors during dairy waste-water treatment. Renewable Energy, 33:960-965.

Government of India (GOI) 2012. Basic Animal Husbandry Statistics. Department of Animal Husbandry, Dairying and Fisheries.

Hanaki, K., Matsuo, T. and Nagase, M. 1981. Mechanism of inhibition caused by long chain fatty acids in anaerobic digestion process. Biotechnology and Bioengineering, 23:1591-1610.

Haridas, A., Suresh, S., Chitra, K. R. and Manilal, V. B. 2005. The buoyant filter bio-reactor: a high rate anaerobic reactor for complex waste water process dynamics with dairy effluent. Water Research, 39:993-1004.

Horiuchi, J. I., Shimizu, T., Tada, K., Kanno, T. and Kobayashi, M. 2002. Selective production of organic acids in anaerobic acid reactor. Bio-resource Technology, 82:209-213.

Hwang, S. H. and Hansen, C. L. 1992. Performance of up-flow anaerobic sludge blanket (UASB) reactor treating whey permeate. Transation ASAE, 35:16651671.

Ince, O., Ince, B. K. and Donnelly, T. 2000. Attachment, strength and performance of a porous media in an up flow anaerobic filter treating dairy wastewater. Water Science Technology, 41(4-5):261-270.

Komatsu, T., Hanaki, K. and Matsuo, T. 1991.
Prevention of lipid inhibition in anaerobic processes by introducing a two-phase system, Water Science Technology, 23:1189-1200.

Koster, I. 1987. Abatement of long-chain fatty acid inhibition of methanogenic by calcium addition. Biological Wastes, 25:51-59.

Leal, M. C. M. R., Freire, D. M. G., Cammarota, M. C., Anna, G. L. and Sant, Jr. 2006. Effect of enzymatic hydrolysis on anaerobic treatment of dairy wastewater. Process Biochemistry, 41:11731178 .

Lusk, P. 1998. Methane recovery from animal manures. The current opportunities casebook No. NREL/SR-580-25145. Pub by National Technical Information Service (NTIS) U.S.

Malaspina, F., Stante, L., Cellamare, C. M. and Tilche, A. 1995. Cheese whey and cheese factory waste-water treatment with a biological anaerobic-aerobic process. Water Science Technology, 32:59-72.

Monroy, O., Johnson, K. A., Wheatley, A. D., Hawkes, F. and Caine, M. 1994. The anaerobic filtration of dairy waste: Results of a pilot trial. Bio-resource Technology, 50:243-251.

Montuelle, B., Coillard, J. and Lehy, J. B. 1992. A combined anaerobic aerobic process for the co-treatment of effluents from a piggery and a cheese factory. Journal of Agricultural Engineering and Research, 51:91-100.

Morgan, J. W., Evison, L. M. and Forster, C. F. 1991. Changes to the microbial ecology in anaerobic digesters treating ice cream wastewater during start up. Water Research, 25:639-653.

Motta-Marques, D. M. L., Cayless, S. M. and Lester, J. N. 1990. Start-up regimes for anaerobic fluidized systems treating dairy wastewater. Biological Wastes, 34:191202.

Nadais, H., Capela, I., Arroja, L. and Duarte, A. 2005. Optimum cycle time for intermittent UASB reactors treating dairy wastewater. Water Research, 39:1511- 
1518.

Omil, F., Garrido, J. M., Arrojo, B. and Mendez, R. 2003. Anaerobic filter reactor performance for the treatment of complex dairy wastewater at industrial scale. Water Research, 37:4099-4108.

Passeggi, M., Lopez, I. and Borzacconi, L. 2009. Integrated anaerobic treatment of dairy industrial wastewater and sludge. Water Science and Technology, 59(3):501-506.

Rajeshwaran, S. and Naik, G. 2016. Milk production in India rises by a historic 6.25 $\%$ in 2014-5: A boon or a bane? WORKING PAPER NO: 518 online access at http://www.iimb.ernet.in/sites/default/file s/research/files/workingpaper/WP\%20No. $\% 20518 . p d f$

Ramasamy, E. V., Gajalakshmi, S., Sanjeevi, R., Jithesh, M. N. and Abbasi, S. A. 2004. Feasibility studies on the treatment of dairy wastewaters with up flow anaerobic sludge blanket reactors. Bio-resource Technology, 93:209-212.

Ramjeawon T. 2000. Cleaner Production in Mauritian Cane-sugar factories. Journal of Cleaner Production, 8(6):503-510.

Rico, J. L., Garcia, P. A. and FernandezPolanco, F. 1991. Anaerobic treatment of cheese production wastewater using UASB reactor. Bio-resource Technology, 37:271-276.

Sharma, P. 2008. Performance evaluation of waste water treatment plant for milk based food industry. M. Tech Thesis submitted to Thapar University, Patiala.

Tawfik, A., Sobhey, M. and Badawy, M. 2008. Treatment of a combined dairy and domestic wastewater in an up-flow anaerobic sludge blanket (UASB) reactor followed by activated sludge (AS system). Desalination, 227:167-177.

Tchobanoglous, G., Burton, F. L. and Stensel, H. D. 2003. Metcalf and Eddy Inc.Waste Water Engineering Treatment and Reuse. Fourth Edition, Tata McGraw-Hill Publishing Company Limited, New Delhi, India.

Tie, L. and Sivakumar, M. 2006. Dairy shed wastewater treatment by anaerobic digestion technology. Environment Working Together - A Multi-Disciplinary Approach: $10^{\text {th }}$ Annual Environment Post-graduate Conference (pp. 282-287). Cairns, QLD AUSTRALIA: James Cook University.

Vidal, G., Carvalho, A., Mendez, R. and Lema, J. M. 2000. Influence of the content in fats and proteins on the anaerobic biodegradability of dairy wastewaters. Bio-resource Technology, 74:231-239.

Viraraghavan, T. and Kikkeri, S. R. 1990. Effect of temperature on anaerobic filter treatment of dairy wastewater. Water Science Technology, 22:191-198.

Viraraghavan, T. and Kikkeri, S. R. 1991. Dairy wastewater treatment using anaerobic filters. Canadian Agricultural Engineering, 33:143-149.

Wheatley, A. 1990. Anaerobic digestion: A waste treatment technology. Elsevier Applied Science, New York.

Yu, H. Q. and Fang, H. H. P. 2002a. Anaerobic acidification of a synthetic wastewater in batch reactors at $55{ }^{\circ} \mathrm{C}$. Water Science Technology, 46(11-12):153-157.

$\mathrm{Yu}, \quad$ H. Q. and Fang, H. H. P. 2002b. Acidogenesis of dairy wastewater at various $\mathrm{pH}$ levels. Water Science Technology, 45(10):201S-206S

\section{How to cite this article:}

Kanchan V. Mogha, Kunal M. Gawai and Arun C. Patel. 2017. Anaerobic Treatments for Dairy Waste Disposal - Ponder for making it Efficient. Int.J.Curr.Microbiol.App.Sci. 6(11): 806-814. doi: https://doi.org/10.20546/ijcmas.2017.611.095 